\title{
Root Pruning Reduces Photosynthesis, Transpiration, Growth, and Fruiting of Container-grown French-American Hybrid Grapevines
}

\author{
D.C. Ferree, D.M. Scurlock, and J.C. Schmid \\ Horticulture and Crop Science, The Ohio State University, Ohio Agricultural \\ Research and Development Center, Wooster, OH 44691-4096
}

Additional index words. Vitis vinifera, stomatal conductance, leaf area, cluster weight, berry weight, dry-weight distribution

\begin{abstract}
Seyval blanc' and 'Vidal blanc' grapevines (Vitis sp.) grown in large containers were root-pruned at different severities and/or stages of development and the effects on growth of both cultivars and fruiting of 'Seyval blanc' were determined. As the severity of root pruning increased, stomatal conductance $\left(g_{s}\right)$ and transpiration $(E)$ decreased and the number of wilted leaves increased in both cultivars. In both cultivars, root pruning reduced net photosynthesis (Pn) and $\mathrm{E}$ for as long as 18 to 20 days, as well as total leaf area and dry weight of leaves and petioles plus tendrils. The reductions were proportional to the degree of root pruning. A similar pattern existed for cane and root tissue of 'Vidal blanc'. As the severity of root pruning increased, berry and cluster weight, and titratable acidity (TA) of 'Seyval blanc' decreased. There was no effect of root pruning on berries per cluster, soluble solids content (SSC), or pH of the juice. No interaction was significant for any factor between time of root pruning and fruiting measured on 'Seyval blanc' vines. Root pruning at bloom reduced leaf area, number of leaves, and dry weight of petioles, trunks, and canes. Root pruning at veraison had no effect on any vegetative or fruit parameters. Fruiting 'Seyval blanc' vines had less leaf area and smaller petiole and cane dry weights than did nonfruiting vines.
\end{abstract}

Root pruning has been used to control growth of many plants (Geisler and Ferree, 1984a, 1984b) including grapes (Dry et al., 1995; Ferree et al., 1994; Poni et al., 1992). However, the effects of root pruning of grapes have been inconsistent. Reviews of the influence of root pruning (Ferree et al., 1992; Geisler and Ferree, 1984a) reveal only a few references on grapes. Buttrose and Mullins (1968) found, through repeated root pruning at various degrees on small potted grapevines, that shoot length and dry weight declined in proportion to the degree of root pruning. They concluded that the growth rate of shoots can be regulated by the size of the root systems and suggested that the effect may be due to a reduction in cytokinins. Thick roots regenerated faster after pruning than did thin roots, and regeneration declined with distance from the main stem (Oniani, 1973; VanZyl and Huyssteen, 1988). Root pruning increased growth and productivity of low-vigor grapevines on compacted soils (VanZyl and

Received for publication 5 Nov. 1998. Accepted for publication 9 Mar. 1999. Salaries and research support provided by state and federal funds appropriated to the Ohio Agricultural Research and Development Center, The Ohio State Univ. Manuscript number 98-26. Partial funding for this project came from The Ohio Grape Industries Program. The cost of publishing this paper was defrayed in part by the payment of page charges. Under postal regulations, this paper therefore must be hereby marked advertisement solely to indicate this fact.
Huyssteen, 1988).Zabadal and Dittmer(1996) found an undesirable reduction in growth following root pruning of grapevines at planting. vigorous, resulting in canopy shading and reduced fruit quality. Research with apple (Malus $\times$ domestica Borkh.) indicated that canopy light penetration and fruit SSC can be improved by root pruning if it is severe enough to reduce growth (Ferree, 1992; Schupp and Ferree, 1987, 1988). Amerine and Josyln (1970) observed that the outer layers of the grape berry (mainly the skin) contain the greater portion of the aroma, coloring, and flavoring constituents, and that the skin : pulp ratio is greatest for small-berried varieties, resulting in the greatest concentration of color and flavor in red cultivars. However, reducing berry size by shading leaves does not enhance wine quality (Morrison, 1988; Smith et al., 1988). Coombe (1992) stated that the vegetative parts of the vine, particularly the roots, may have significant influence on the development and ripening of the berry. Root pruning consistently reduced size and increased red color of apple (Ferree, 1992; Ferree and Knee, 1997; Schupp and Ferree, 1987, 1988), which would be desirable outcomes for wine grapes.

\section{Materials and Methods}

Expt. 1. 'Vidalblanc'. Degree of root pruning of nonfruiting vines. All experiments were $15 \pm 3{ }^{\circ} \mathrm{C}$ night temperatures with natural
On many sites, grapevines become too performed in a greenhouse set at $21 \pm 3^{\circ} \mathrm{C}$ day/ daylength. Own-rooted 'Vidal blanc' vines previously grown for 1 year in pots were removed from cold storage and planted in the center of square $24-\mathrm{L}$ containers with removable sides, containing a medium of equal parts peat, perlite, and Wooster silt loam soil (fine, loamy mixed mesic typic Fragiudalf). The vines were cut back to a single node and trained as a single shoot with laterals and clusters removed as they developed. Each container was fertilized with $15 \mathrm{~g}$ of Osmocote (Scotts-Sierra, Marysville, Ohio) 14N-6P$12 \mathrm{~K}$. The vines were watered and received insecticide applications as needed. Root pruning treatments were applied when new growth reached an average length of $63 \mathrm{~cm}$ on $14 \mathrm{Apr}$. 1994.

To achieve several degrees of root pruning, the soil column was cut perpendicular to the container bottom on two opposite sides, using a sharpened steel sheet, at one of the following distances from the trunk: $2,4,6$, or $8 \mathrm{~cm}$. Controls were not pruned. The severed roots were left in the container to minimize disturbance of the medium. The treatments were arranged as a randomized complete block on the greenhouse bench with six single-vine replications. Six additional vines were harvested at the time of root pruning to quantify pruning severity and dry-weight partitioning among roots, trunk, shoot, and leaves.

A steady-state porometer (LI-COR 1600, Lincoln, Nebr.) was used to estimate $g_{\mathrm{s}}$ and $\mathrm{E}$ on a fully expanded leaf, 1 and $24 \mathrm{~h}$ after root pruning. In addition, the number of wilted leaves per plant was counted 6 and $24 \mathrm{~h}$ after root pruning. The sixth leaf from the shoot tip was tagged and shoot length beyond this leaf was measured weekly. Net photosynthesis and E were measured regularly, beginning $1 \mathrm{~d}$ after root pruning, using the youngest fully expanded leaf under saturated light conditions. A portable infrared gas analyzer equipped with a $6.25 \mathrm{~cm}^{2}$ leaf chamber (model LCA2; Analytical Development Co., Hoddesdon, England) was used; air flow rate was regulated at $300 \mathrm{~mL} \cdot \mathrm{min}^{-1}$ and ambient $\mathrm{CO}_{2}$ concentration was monitored periodically during each series of measurements.

The study was concluded $70 \mathrm{~d}$ after root pruning because of the very large size of unpruned vines. All plants were harvested, and tissues separated and dried in a forceddraft oven at $70^{\circ} \mathrm{C}$ to determine dry weights.

Expt. 2. 'Seyval blanc'. Degree of root pruning offruiting vines. The previous experiment evaluated varying degrees of root pruning on nonfruiting vines. This study determined the effect of the same root-pruning treatments on a less vigorous cultivar with fruit. Own-rooted 'Seyval blanc' vines grown for 1 year in pots were removed from cold storage and handled as previously described in Expt. 1. A single cluster was retained on each vine. The new shoots averaged $65 \mathrm{~cm}$ in length and bore 13 leaves at the time of root pruning on 13 Mar. 1995. The stage of development varied from full bloom to 4-mm berries. Vines were blocked by stage of development, with the most advanced vines in replicate one to the least advanced in replicate six. Since we de- 
Table 1. Influence of increasing severity of root pruning on stomatal conductance, transpiration, and wilting of container-grown vines of 'Vidal blanc' in 1994 and 'Seyval blanc' in 1995.

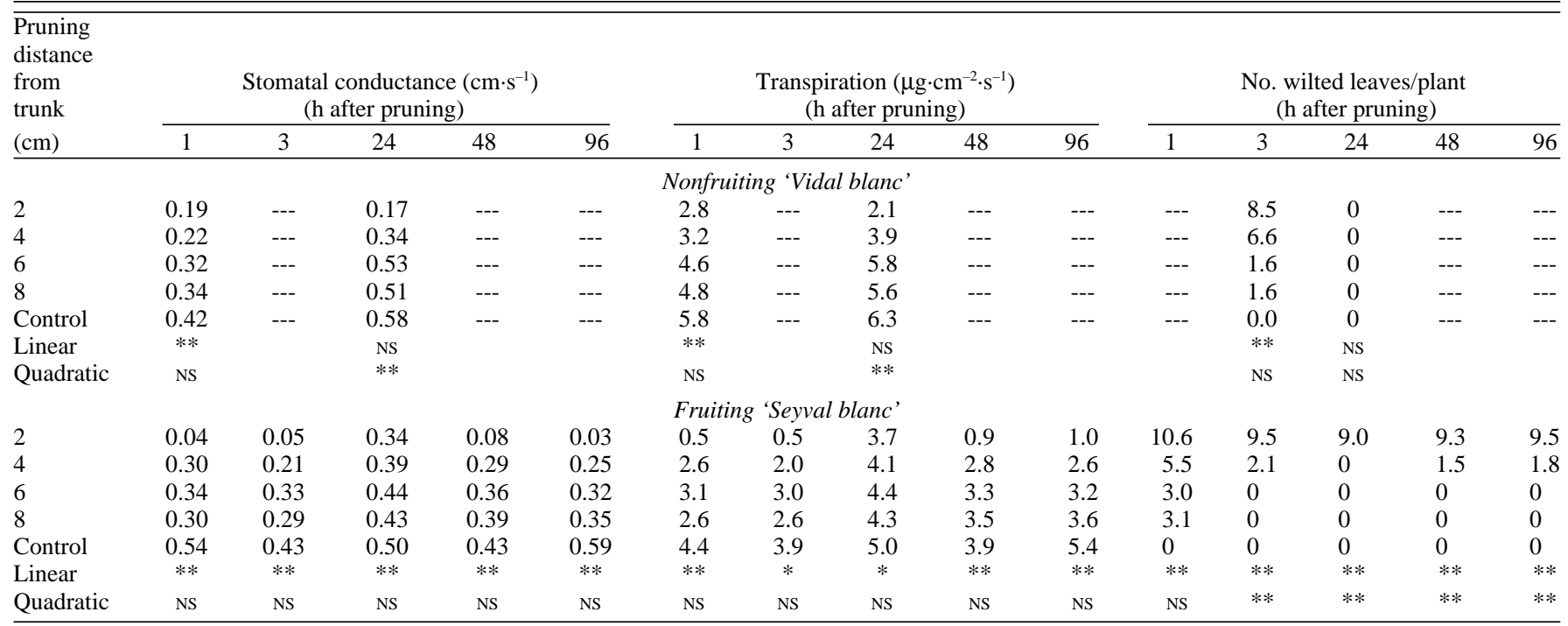

ws, ****Nonsignificant or significant at $P \leq 0.05$ or 0.01 .

sired to carry the fruit to maturity, and to avoid excessively large vines that could not be easily moved for measurement, vine size was limited to 13 fully expanded leaves on 30 Mar. 1995 by the removal of lateral shoots as they developed. In addition to the measurements made in Expt. 1, clusters were harvested and weighed at maturity, and shot berries counted and then pressed through a fruit strainer to obtain SSC, $\mathrm{TA}$, and $\mathrm{pH}$ of the juice.

Expt. 3. 'Seyval blanc'. Effects of time of root pruning on fruiting and nonfruiting vines. Vines in this study were identical to those used in Expt. 2, except that root pruning at $4 \mathrm{~cm}$ on either side of the trunk was performed at bloom on 17 Mar. 1995, or at veraison on 9 May 1995. Half of the vines in this study had no fruit and half had one cluster. Treatments were arranged as a factorial of crop level (zero vs. one cluster) and time of root pruning (unpruned, pruned at bloom, or pruned at veraison). Data on dry-weight distribution, cluster development, and fruit composition were collected as previously described.

Statistical analysis. In all these experiments, treatments were arranged as a randomized complete block with six single-vine replications and the data were analyzed using SAS 6.12 (SAS Institute, 1996).

\section{Results and Discussion}

Expts. 1, 2. Initial response to root pruning. Generally, as the degree of root pruning increased, $g_{\mathrm{s}}$ and E were reduced, and the number of wilted leaves increased in both cultivars (Table 1). The two most severe treatments caused a significant reduction in $g_{\mathrm{s}}$ and E within $1 \mathrm{~h}$, which persisted for several days. Generally, the effects of root pruning were greater on the fruiting 'Seyval blanc' than on nonfruiting 'Vidal blanc', although the cultivars cannot be statistically compared. Wilting was more severe and lasted longer in fruiting 'Seyval blanc' than in 'Vidal blanc', but leaves on both cultivars recovered and persisted until the plants were harvested. The greater effect of root pruning on 'Seyval blanc' could be the result of the influence of fruit, as reported for apple (Schupp et al., 1992).

$P n$ and E over time. As the severity of root pruning increased, Pn was reduced for both cultivars for the 18 to $20 \mathrm{~d}$ following pruning (Fig. 1). Measurements for 'Seyval blanc' made later than 18 to $20 \mathrm{~d}$ after pruning indicated a return of Pn to control values. The same general pattern existed for E. Poni et al. (1992) found that for potted grape (Vitis vinifera), apple, peach (Prunus persica Batsch.), and pear (Pyrus communis L.) transpiration
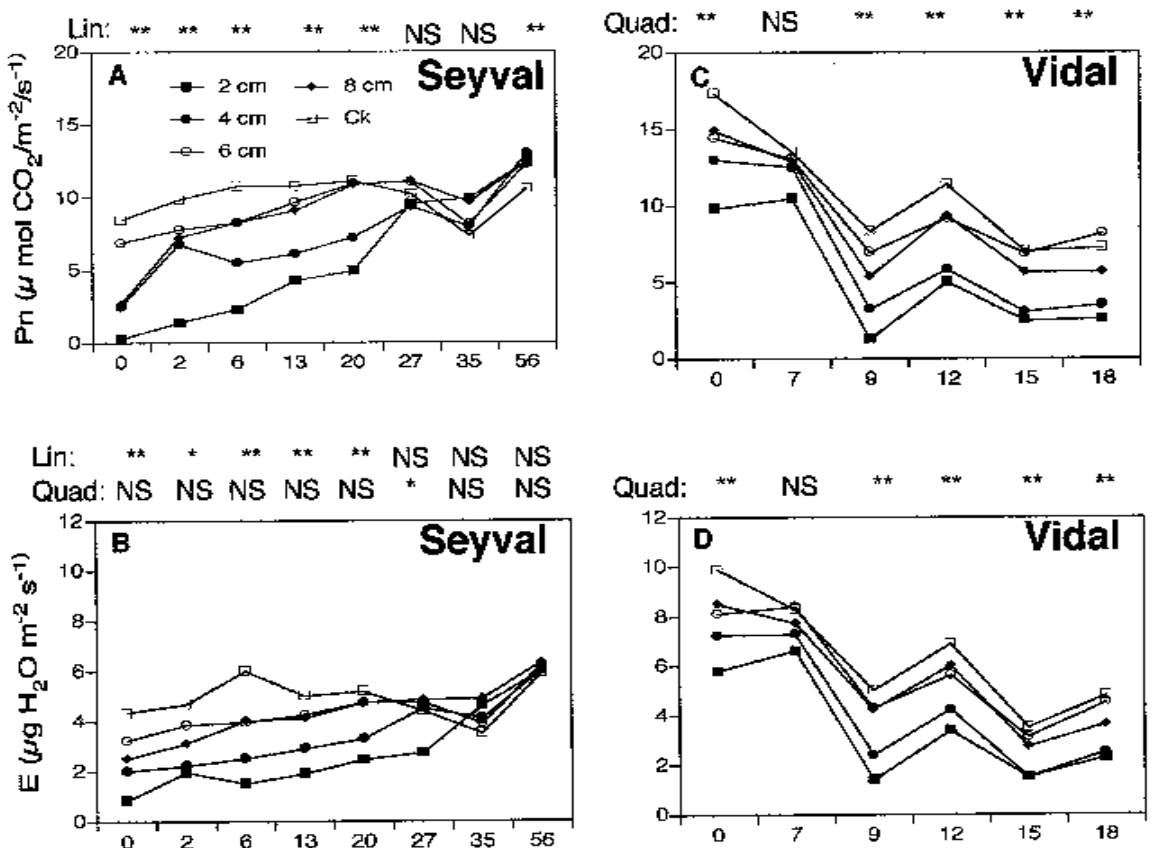

\section{Days After Root Pruning}

Fig. 1. Influence of root pruning to 2 to $8 \mathrm{~cm}$ from the trunk on net photosynthesis (Pn) and transpiration (E) of container-grown, fruiting 'Seyval blanc' vines in 1995, and nonfruiting 'Vidal blanc' vines in 1994. ws, ,***Nonsignificant or significant at $P \leq 0.05$ or 0.01 . 
$82 \%$ for Pn and E, respectively. The reductions in Pn and $\mathrm{E}$ at 18 or $20 \mathrm{~d}$ after pruning were similar for both cultivars.

Dry-weight partitioning. As the severity of root pruning increased, total leaf area and dry weight of leaves, petioles, and tendrils of both cultivars decreased (Table 2). A similar pattern existed for cane and root tissues of 'Vidal blanc', but not of 'Seyval blanc'. Calculation of the relative percentages of each of the tissues generally revealed similar distributions, with the exception of trunk tissue, which generally comprised a higher percentage of the total as pruning severity increased. Vines of both cultivars had grown to about the same height at the time of root pruning and in the same containers and medium; nevertheless, the percent dry weight of the root system removed was much greater with each treatment for nonfruiting 'Vidal blanc' than for fruiting 'Seyval blanc', as measured on six representative vines harvested at the time of root pruning. Morano and Kliewer (1994) found that grapevine root distribution was influenced by rootstock cultivar, and root density was positively related to vigor. Thus, more roots may have been removed from the ownrooted 'Vidal blanc' vines in root pruning because of the greater density of the root system in the potting medium. The dry weights of the roots appeared similar for the two cultivars, although they cannot be compared statistically.

A previous study (Geisler and Ferree, 1984b) on the influence of increasing degrees of root pruning on vegetative apple trees, using the same containers and techniques, revealed that when $59 \%$ of the roots were removed, total leaf area was reduced by $42 \%$ and total fresh weight by $26 \%$. 'Seyval blanc' was reasonably similar, with removal of $46 \%$ of the roots causing a $57 \%$ reduction in leaf area and a $27 \%$ reduction in total dry weight. The 6$\mathrm{cm}$ root pruning treatment with 'Vidal blanc' removed $58 \%$ of the roots, which was similar to apple, but caused only a $20 \%$ reduction in leaf area and a $7 \%$ (nonsignificant) reduction in total dry weight. Thus, much more severe root pruning was necessary to cause significant and similar reductions for these tissues in 'Vidal blanc' than in apple. Fruit production in 'Seyval blanc' may have been responsible for a portion of the difference between grape cultivars. Root pruning reduced growth more in fruiting than in defruited apple trees (Schupp et al., 1992). Poni et al. (1992) found grape less responsive to removal of $50 \%$ of the root system than were apple and peach trees treated similarly. In their study, grapes produced more new roots than apple, pear, and peach on the half of the root system that remained after pruning. Buttrose and Mullins (1968) also found that shoot length and dry weight of small potted vines declined in proportion to the amount of root tissue removed.

Effects of root pruning on yield components and fruit composition. As the severity of root pruning increased, the cluster and berry weight and TA of 'Seyval blanc' decreased (Table 3). There was no effect of root pruning on fully developed berries/cluster, SSC, or $\mathrm{pH}$.
However, the number of shot berries/cluster root pruning. Root pruning generally reduces fruit size of apple (Ferree, 1992; Ferree and Knee, 1997; Schupp and Ferree, 1987; Schupp et al., 1992) and may (Ferree and Knee, 1997; Ferree and Rhodus, 1993) or may not (Miller, 1995; Schupp et al., 1992) reduce yield . Apple SSC was increased by root pruning (Schupp and Ferree, 1987, 1988), but SSC of grapes were not influenced in field studies (Ferree et al., 1994) or in the greenhouse, where the effects on vegetative growth were evident (Table 3).

Expt. 3. Time of root pruning. No interaction occurred between fruiting and time of root pruning with 'Seyval blanc' vines. Root pruning $4 \mathrm{~cm}$ from the trunk at bloom reduced leaf area and number of leaves per vine (Table 4) and the dry weight of petioles, trunk, and cane, while root pruning at veraison affected only root dry weight. Field studies evaluating root pruning of grapevines indicated that pruning near bloom was most effective in controlling growth (Dry et al., 1995; Ferree et al., 1994). This study supports the concept that cultivars differ in response to root pruning. Fruiting and nonfruiting vines did not differ significantly in total dry weight. Thus, fruiting probably had little effect on cultivar differences in response to root pruning (Table 2 ). In a previous field tended to increase with moderate degrees of

study, growth of 'Seyval blanc' and 'White Riesling' was reduced more by root pruning than was that of 'Delaware' (Ferree et al., 1994).

In summary, root pruning can decrease vegetative growth. Berry weight was reduced in one study (Table 3), but not in the second (Table 4), with no other effects on fruit composition. The severity of root pruning must be greater in grape than in apple to obtain similar responses. Differences may exist among grape cultivars in their response to root pruning; 'Seyval blanc' may be more sensitive than 'Vidal blanc'.

\section{Literature Cited}

Amerine, M.A. and M.A. Joslyn. 1970. Table wines: The technology of their production. 2nd ed. Univ. of California Press, Los Angeles.

Buttrose, M. and M.G. Mullins. 1968. Proportional reduction in shoot growth of grapevines with root system maintained at a constant relative volume by repeated pruning. Austral. J. Biol. Sci. 21:1095-1101.

Coombe, B.G. 1992. Research on development and ripening of the grape berry. Amer. J. Enol. Viticult. 43:101-110.

Dry, P., D. Bottling, B. Loveys, and A. Johnstone. 1995. Root pruning as a potential method for vigour control-some preliminary results, p. 1516. Austral. Grape Grower and Winemaker, Adelaide.

Table 2. Influence of increasing severity of root pruning on leaf area, leaves per vine, and dry-weight distribution of 'Vidal blanc' (1994) and 'Seyval blanc' (1995) vines in the greenhouse.

\begin{tabular}{|c|c|c|c|c|c|c|c|c|}
\hline \multirow[b]{2}{*}{$\begin{array}{l}\text { Pruning distance } \\
\text { (cm from trunk) }\end{array}$} & \multirow{2}{*}{$\begin{array}{l}\text { Total } \\
\text { leaf } \\
\text { area } \\
\left(\mathrm{cm}^{2}\right)\end{array}$} & \multirow[b]{2}{*}{$\begin{array}{c}\text { Leaves/ } \\
\text { vine }\end{array}$} & \multicolumn{5}{|c|}{ Dry-weight distribution (g) } & \multirow[b]{2}{*}{$\begin{array}{c}\text { Roots }^{\mathrm{z}} \\
\text { removed } \\
(\%)\end{array}$} \\
\hline & & & $\begin{array}{c}\text { Petioles } \\
\text { and } \\
\text { tendrils }\end{array}$ & Cane & Trunk & Root & Total & \\
\hline \multicolumn{9}{|c|}{ Nonfruiting 'Vidal blanc' } \\
\hline 2 & 465 & 23.3 & 5.2 & 31.3 & 16.9 & 13.1 & 90.0 & 78 \\
\hline 4 & 578 & 28.4 & 7.6 & 40.5 & 15.9 & 16.2 & 108.8 & 69 \\
\hline 6 & 639 & 38.5 & 12.4 & 61.6 & 18.9 & 23.6 & 155.3 & 58 \\
\hline 8 & 646 & 37.3 & 11.4 & 55.0 & 16.4 & 23.4 & 143.8 & 40 \\
\hline Control & 799 & 42.6 & 13.8 & 73.2 & 16.0 & 21.2 & 167.0 & 0 \\
\hline Linear & $* *$ & $* *$ & $* *$ & $* *$ & NS & $* *$ & $* *$ & --- \\
\hline Quadratic & NS & NS & NS & NS & NS & NS & NS & --- \\
\hline \multicolumn{9}{|c|}{ Fruiting 'Seyval blanc' } \\
\hline 2 & 1053 & 9.6 & 1.6 & 6.1 & 17.7 & 14.3 & 47.4 & 46 \\
\hline 4 & 1937 & 19.8 & 2.6 & 10.6 & 17.7 & 19.6 & 61.3 & 41 \\
\hline 6 & 2214 & 17.8 & 3.9 & 11.3 & 19.5 & 27.8 & 75.7 & 14 \\
\hline 8 & 2135 & 18.0 & 2.8 & 10.8 & 20.2 & 25.5 & 70.2 & 13 \\
\hline Control & 2442 & 16.1 & 5.2 & 11.2 & 21.9 & 13.1 & 64.5 & 0 \\
\hline Linear & $* *$ & $*$ & $* *$ & NS & NS & NS & $*$ & --- \\
\hline Quadratic & $*$ & $* *$ & NS & NS & NS & $* *$ & $*$ & --- \\
\hline
\end{tabular}

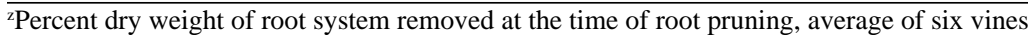

Ns, *, ** Nonsignificant or significant at $P \leq 0.05$ or 0.01 .

Table 3. Influence of increasing severity of root pruning on weight per cluster and per berry, berries per cluster and fruit composition of container-grown 'Seyval blanc' grapes grown in the greenhouse.

\begin{tabular}{|c|c|c|c|c|c|c|c|}
\hline \multirow{3}{*}{$\begin{array}{l}\text { Pruning distance } \\
\text { (cm from trunk) }\end{array}$} & \multirow{2}{*}{\multicolumn{2}{|c|}{ Wt (g) per: }} & \multicolumn{2}{|c|}{ Berries/cluster } & & & \\
\hline & & & Fully & & \multicolumn{3}{|c|}{ Fruit composition } \\
\hline & Cluster & Berry & developed & Shot & $\mathrm{SSC}^{\mathrm{z}}$ & $\mathrm{TA}^{\mathrm{z}}$ & $\mathrm{pH}$ \\
\hline 2 & 71.0 & 1.50 & 46.5 & 11.5 & 20.0 & 6.5 & 3.36 \\
\hline 4 & 85.8 & 1.62 & 53.4 & 31.2 & 20.7 & 6.5 & 3.51 \\
\hline 6 & 131.8 & 1.84 & 71.6 & 22.6 & 21.3 & 6.7 & 3.45 \\
\hline 8 & 120.3 & 1.62 & 75.8 & 33.5 & 20.8 & 6.8 & 3.42 \\
\hline Control & 128.0 & 1.92 & 67.6 & 17.0 & 21.9 & 7.1 & 3.46 \\
\hline Linear & $* *$ & $*$ & $*$ & NS & NS & $* *$ & NS \\
\hline Quadratic & NS & NS & NS & $*$ & NS & NS & NS \\
\hline
\end{tabular}

${ }^{\mathrm{z}} \mathrm{SSC}=$ soluble solids concentration $(\%) ; \mathrm{TA}=$ titratable acidity $\left(\mathrm{g} \cdot \mathrm{L}^{-1}\right)$.

Ns, *,*** Nonsignificant or significant at $P \leq 0.05$ or 0.01 . 
Table 4. Influence of time of root pruning $4 \mathrm{~cm}$ from the trunk of container-grown 'Seyval blanc' grapevines and presence of a fruit cluster on total leaf area, leaves per vine, dry-weight distribution, weight per cluster and per berry, and cluster and fruit composition in 1995.

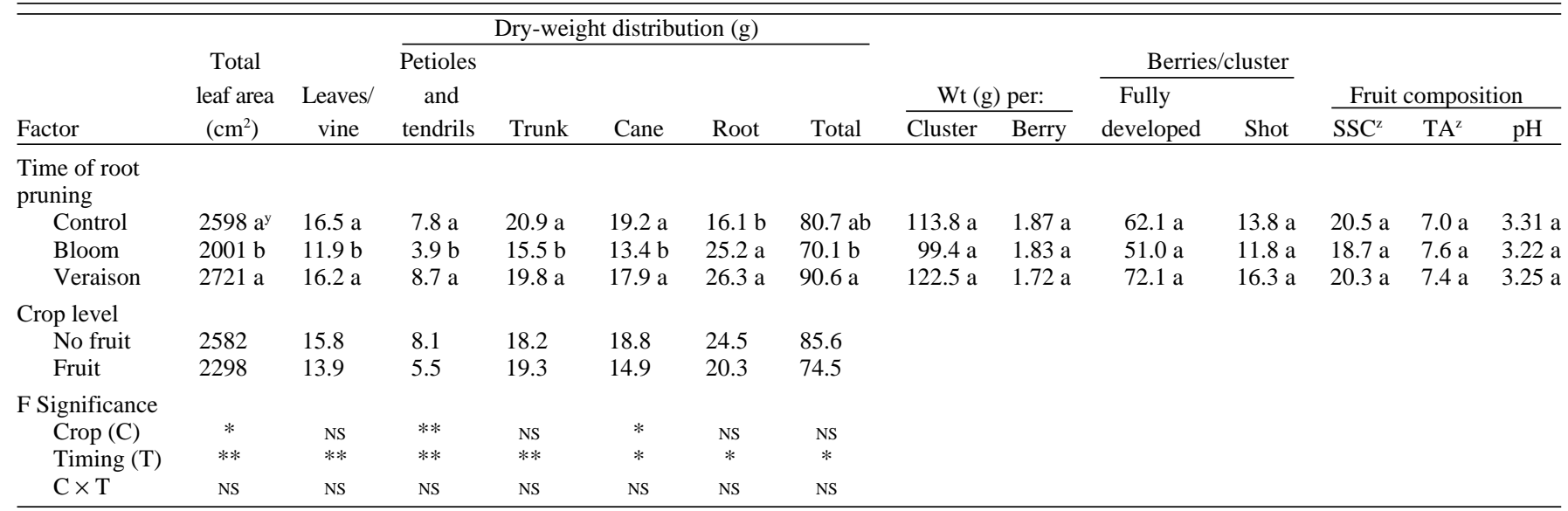

${ }^{2} \mathrm{SSC}=$ soluble solids concentration $(\%) ; \mathrm{TA}=$ titratable acidity $\left(\mathrm{g} \cdot \mathrm{L}^{-1}\right)$.

y Mean separation within columns and factors by Duncan's multiple range, $P \leq 0.05$.

ss, *,**Nonsignificant or significant at $P \leq 0.05$ or 0.01 .

Ferree, D.C. 1992. Time of root pruning influences vegetative growth, fruit size, biennial bearing and yield of 'Jonathan' apple. J. Amer. Soc. Hort. Sci. 117:198-202.

Ferree, D.C., A. Erb, and D. Scurlock. 1994. Root pruning-A potential technique to control growth of grapes, p. 54-57. In: Proc. Ohio Grape-Wine Short Course.

Ferree, D.C. and M. Knee. 1997. No interaction between root pruning and rootstock on growth and performance of 'Golden Delicious' apple. HortScience 32:645-648.

Ferree, D.C. and W.T. Rhodus. 1993. Apple performance with mechanical hedging or root pruning in intensive orchards. J. Amer. Soc. Hort. Sci. 118:707-713.

Ferree, D.C., J.R. Schupp, and S.C. Myers. 1992. Root pruning and root restriction of fruit treesCurrent review. Acta Hort. 322:153-166.

Geisler, D. and D.C. Ferree. 1984a. Response of plants to root pruning. Hort Rev. 6:155-188.

Geisler, D. and D. Ferree. 1984b. The influence of root pruning on water relations, net photosynthesis, and growth of young 'Golden Delicious' apple trees. J. Amer. Soc. Hort. Sci. 109:827831.

Hansen, P. 1970. ${ }^{14} \mathrm{C}$ studies on apple trees. VI. The influence of the fruit on the photosynthesis of the leaves and the relative photosynthetic yields of fruits and leaves. Physiol. Plant. 23:805-810.

Kaps, M.L. and G.A. Cahoon. 1989. Berry thinning and cluster thinning influence vegetative growth, yield, fruit composition, and net photosynthesis of 'Seyval blanc' grapes. J. Amer. Soc. Hort. Sci. 114:20-24.

Miller, S.S. 1995. Root pruning and trunk scoring have limited effect on young bearing apple trees. HortScience 30:981-984.

Morano, L.D. and W.M. Kliewer. 1994. Root distribution of three grapevine rootstocks grafted to Cabernet Sauvignon grown on a very gravely loam soil in Oakville, CA. Amer. J. Enol. Viticult. 45:345-348.

Morrison, J.C. 1988. The effects of shading on the composition of Cabernet Sauvignon grape berries, p. 144-146. In: Proc. 2nd Intl. Symp. Cool Climate Viticult. and Oenology.

Oniani, D.V. 1973. The effect of severing grapevine roots on their regeneration. Hort Abstr. 45:1459.

Poni, S., M. Tagliavini, D. Neri, D. Scudellari, and M. Toselli. 1992. Influence of root pruning and water stress on growth and physiological factors of potted apple, grape, peach and pear trees. Scientia Hort. 52:223-236.
Schupp, J.R. and D.C. Ferree. 1987. Effect of root pruning at different growth stages on growth and fruiting of apple trees. HortScience 22:387390.

Schupp, J.R. and D.C. Ferree. 1988. Effects of root pruning at four levels of severity on growth and yield of 'Melrose' /M.26. J. Amer. Soc. Hort. Sci. 113:194-198.

Schupp, J.R. and D.C. Ferree. 1990. Influence of time of root pruning on growth, mineral nutrition, net photosynthesis, and transpiration of young apple trees. Scientia Hort. 42:299-306

Schupp, J.R., D.C. Ferree, and I.J. Warrington. 1992. Interactions of root pruning and deblossoming on growth, development, and yield of 'Golden Delicious' apple. J. Hort Sci. 67:465480.

Smith, S., I.C. Codrington, M. Robertson, and R.E. Smart. 1988. Viticultural and oenological implication of leaf removal for New Zealand vineyards, p. 127-133. In: Proc. 2nd Intl. Symp. Cool Climate Viticult. and Oenology.

VanZyl, J.L. and L. Van Huyssteen. 1988. Root pruning. Farming in South Africa. p. 1-3.

Zabadal, T. and T. Dittmer. 1996. Grapevine root pruning influences performance. Great Lakes Fruit Growers News. Feb. p. 24-25. 